GEOSECS and Transient Tracers in the Ocean (TTO) studies considered by Fanning. Our results are presented in the table and suggest that the surface waters of this area of the Sargasso Sea are deficient in both nitrogen and phosphorus for most of the time, rather than phosphorusdeficient as suggested by Fanning. The two data sets are different in that one provides geographical coverage and the other is a time series at a single point, but we would argue from the station $\mathrm{S}$ data set that the situation suggested by Fanning is not necessarily the general case.

A more fundamental point, however, involves the extrapolation of nutrient detectability, as described above and in Fanning's paper, with nutrient limitation because there is clear evidence that high rates of primary productivity can be sustained at very low nutrient concentrations by intense nutrient recycling. Therefore considerations of nutrient limitation based on rates of nutrient consumption and carbon production would be more appropriate.

T. JICKELLS

School of Environmental Sciences,

University of East Anglia,

Norwich NR4 7TJ, UK

A. H. KNAP

R. SHERRIFF-DOW

Bermuda Biological Station,

Ferry Reach, GEO1, Bermuda

J. GALLOWAY

Department of Environmental Sciences,

University of Virginia,

Charlottesville, Virginia 22903, USA

1. Fanning, K. Nature 339, 460-463 (1989).

2. Bigg, G.R., Jickells, T.D., Knap, A.H. \& Sherriff-Dow, R. Oceanologica Acta 12, 437-442 (1989).

3. Knap, A.H., Jickells, T.D., Pszenny, A. \& Galloway, J. Nature 320, 158-160 (1986)

4. Goldman, J.C., Mcarthy, J.J. \& Peavey, D.G. Nature 279, 210-215 (1979).

\section{Genetic basis of grammar defect}

SIR-Vargha-Khadem and Passingham and Fletcher ${ }^{2}$ in their responses to my Scientific Correspondence present no data or arguments to challenge my hypothesis $^{3}$ that there is a deficit in the ability of my subjects to construct an underlying grammer for abstract morphemes like number and tense. They suggest that other subjects in this heterogeneous clinical category have other problems. That is to be expected, but it is also true that the kind of errors that I cite are widely reported in the literature. They say that the subjects in the family in question make additional kinds of errors, some of which I would dispute, but they fail to show that they are relevant to the hypothesis which I have proposed.

What really is at stake here are not the data, but rather how to account for them. My explanation hypothesizes that the subjects are impaired because they cannot

\title{
How many NMDA receptors?
}

SIR-The distinction between glutamate receptors coupled to ion channels is based on their selective activation by different agonists. Three main subtypes have thus been defined: NMDA, kainate and

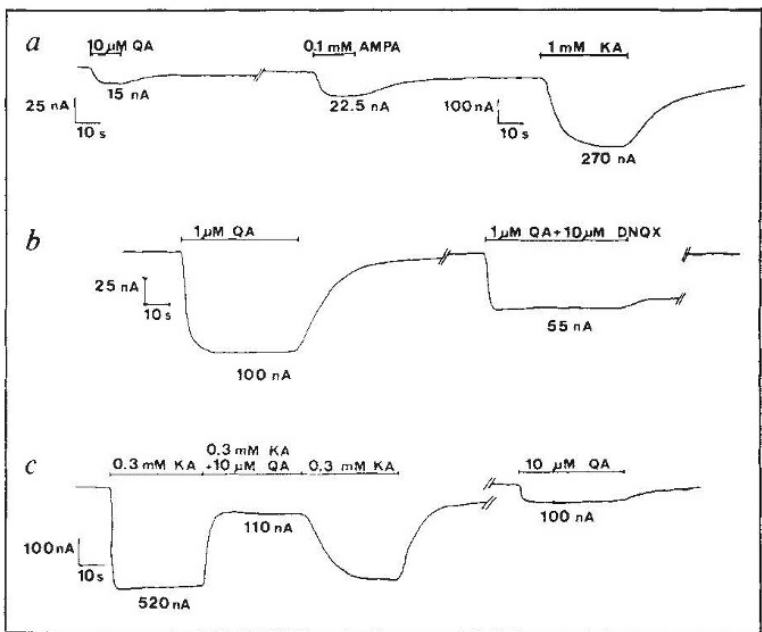

Currents induced in Xenopus oocytes injected with GluR-K1 transcripts. Records from oocytes clamped at $-60 \mathrm{mV}$. a, Responses to quisqualate (QA), kainate (KA) and AMPA (5 ng transcripts). $b$, Antagonism of QA by DNQX. $c$, During a prolonged application of KA, QA reduced the KA response to the level attained with QA alone. Traces $b, c$ are from the same oocyte injected with $20 \mathrm{ng}$ transcripts. Technical details available from $J$.R. on request.

quisqualate receptors ${ }^{1.2}$, although the last two may activate the same receptor ${ }^{3}$. The recent report by Hollmann et al. ${ }^{4}$, of the cloning of GluR-K1 complementary DNA encoding a protein of relative molecular mass 100,000 which, after in vitro transcription and expression in Xenopus oocytes, induces kainate but no quisqualate

1. Mayer, M.L. \& Westbrook, G.L. Prog. Neurobiol. 28, 197$276(1987)$

2. Verdoorn, T.A. \& Dingledine, R. Molec. Pharmac. 34, 298 307 (1988)

3. Rassendren, F.A., Lory, P., Pin, J.P., Bockaert, J. \& Nargeot, J. neurosci. Lett. 99, 333-339 (1989)

4. Hollmann, M., O'Shea-Greenfield, A., Rogers, S.W. \& Heinemann. S. Nature 342, 643-648 (1989).

construct language rules at the necessary level of abstraction ${ }^{+}$. Your correspondents $^{1.2}$ prefer an explanation which hypothesizes that the subjects are impaired because they cannot hear or cannot pronounce certain sounds, and this indirectly affects the grammer carried by these sounds. A wide range of data can be explained by my hypothesis but not by theirs. The data clearly show that it is not the marker $e d$ or $s$ which is impaired, but the underlying grammatical categories of number and tense. Moreover, the data confirm that all such features are impaired, even those like aspect, for which the surface marking is produced.

There is now evidence from twin studies $^{5}$ and from large statistical studies ${ }^{6}$ which is consistent with the hypothesis that developmental language impairments may be linked to an autosomally dominant response suggests the existence of two separate non-NMDA receptors.

We have further characterized the GluR-K1 clone expressed in oocytes and find that it indeed responds to kainate but also to quisqualate (see figure). Responses induced by kainate and quisqualate are blocked by DNQX, and GluR-K1 has a higher affinity for quisqualate than for kainate. (The maximally effective quisqualate concentration elicited only about a tenth of the maximal response to kainate.) During a prolonged application of kainate, addition of quisqualate reduces the recorded current to the level obtained with quisqualate alone (see figure). Currents induced by kainate, quisqualate and domoate display similar sensitivity to membrane potential and show pronounced inward rectification.

Our demonstration that a single protein expressed from a single complementary DNA responds to quisqualate and kainate with the same current-voltage curve supports the hypothesis that the in vivo responses to these agonists are mediated by the same nonNMDA glutamate ionotropic receptors.

BERTRAND LAMBOLEZ PASCALE CURUTCHET JACQUES STINNAKRE PIOTR BREGESTOVSKI* JEAN ROSSIER

LIA PRADO DE CARVALHO

Centre d'Etudes du Système Nerveux, CNRS, 91198 Gif sur Yvette,

Cedex, France.

*Permanent address: USSR Cardiology Research Centre Academy of Medical Sciences, Moscow USSR.

gene. The exciting question is what does this gene do? Does it affect some peripheral aspect of language processing which only indirectly has consequences for language, or does it directly affect the capacity to acquire language? The abstract morpheme hypothesis supports the latter view and provides a more complete account of the data.

Department of Linguistics,

M. GOPNIK

McGill University,

Montreal, Quebec,

Canada H3A 1 G5

1. Vargha-Khadem, F. \& Passingham R.E. Nature 346, 226 (1990).

2. Fletcher, P. Nature 346, 226 (1990)

3. Gopnik, M. Nature 344, 715 (1990).

3. Gopnik, M. Nature $344,715(1990)$.

5. Borges-Osorio, M.R.L. \& Salazano, F. Acta Geneticae med. gemell. 34, 95-100 (1985).

6. Tomblin, J.B. J. Speech Hear. Disord. 54, 287-295 (1989). 